\title{
МИСТЕЦТВОЗНАВСТВО
}

\author{
Antstucties
}

\section{VASYL YERMYLOV AMONG THE "ADEPTS" OF THE NEW VISUALITY}

\section{ВАСИЛЬ ЄРМИЛОВ СЕРЕД «АДЕПТІВ» НОВОЇ ВІЗУАЛЬНОСТІ}

\section{Abstract}

The purpose of the research is to reveal the specifics of the visual language of the artist and designer Vasyl Yermylov, in particular, through the study of his diptych «On the Beach» in interconnection with the artistic and theoretical achievements of Bauhaus artists-innovators. Research methodology. The method of deconstruction, structural, formal-stylistic and comparative analysis is applied in the article. Scientific novelty of the research. The results of the study revealed tendencies for Yermylov to create avant-garde compositions based on a subtle creative dialogue with the theoretical approaches of the Bauhaus representatives, which testifies not only to programmatic and ideological unity, but also to the identity of visual thinking. The method of deconstruction and structural analysis allowed to identify the elements of form as certain structures, deliberately introduced into the work by the master in order to rethink it, create another combination and, thus, the assertion of new content. This is the first time such analysis of Yermylov's works has been conducted. Conclusions. The results

\author{
Ліліана Вежбовська, \\ https://orcid.org/0000-0003-1886-1477 \\ кандидат мистецтвознавства, \\ доцент, \\ Київський національний університет \\ культури і мистецтв, \\ Київ, Україна \\ lilianavezhbovska@gmail.com
}

Мета дослідження - виявити специфіку візуальної мови художника і дизайнера Василя Єрмилова, зокрема, через дослідження його диптиху «На пляжі» у взаємозв'язку з мистецькими і теоретичними напрацюваннями митців-новаторів Баугаузу. Методологія дослідження. У статті застосовано метод деконструкції, структурного, формально-стилістичного та компаративного аналізу. Наукова новизна дослідження. Результати дослідження виявили тенденції до творення Єрмиловим авангардних композицій на основі тонкого творчого діалогу з теоретичними підходами представників Баугаузу, що засвідчує не лише програмну й світоглядну єдність, але й ідентичність візуального мислення. Метод деконструкції та структурного аналізу дозволив виявити елементи форми як структури, свідомо введені у твір майстром з метою його переосмислення, створення іншої комбінації і, таким чином, ствердження нового змісту. Такий аналіз щодо творів Єрмилова проводиться вперше. Висновки. Результати аналізу 
of the analysis of Yermylov's diptych «On the Beach» testify to the universality of the new visual language, Kwhich has developed in Ukraine despite the attempts to adapt it to the service of the totalitarian regime. Today it is important to testify that Ukrainian artists developed in harmony with their Western counterparts. Ermylov's work, built on rethinking of different, sometimes opposite approaches to the development of form, which existed at different stages in the Bauhaus, is an example of exceptional design skill of the Kharkiv artist in composing virtuoso compositions from elements of art form. At the same time, the diptych with its laconic expression of the theoretical avant-garde heritage under the «mask» of Dadaism is a tribute to the New Art in the conditions of its prohibition and destruction

\section{Key words:}

Vasyl Yermylov, Laszlo Moholy-Nagy, Vasyl Kandinsky, Paul Klee, Ukrainian avant-garde, Bauhaus, new visuality, picturesque elements, structures, picture plane, nude. диптиху Єрмилова «На пляжі» засвідчують універсальність нової візуальної мови, що в Україні склалась всупереч намаганням пристосувати іï до обслуговування тоталітарного режиму. Сьогодні важливо засвідчити, що українські митці розвивалися суголосно зі своїми західними колегами. Робота Єрмилова, вибудувана на переосмисленні різних, часом протилежних підходів до розвитку форми, які існували на різних етапах у Баугаузі, $є$ зразком виняткової дизайнерської майстерності харківського митця у складанні віртуозних композицій з елементів мистецької форми. Разом з тим, диптих з його лаконічним виразом теоретичного авангардного спадку під «маскою» дадаїзму $€$ даниною Новому мистецтву в умовах його заборони і знищення.

\section{Ключові слова:}

Василь Єрмилов, Ласло Могой-Надь, Василь Кандинський, Пауль Клеє, український авангард, Баугауз, нова візуальність, живописні елементи, структури, картинна площина, ню.

Introduction 1

Today, scholars are particularly interested in the similarity of the creative methods of the artists who represented the Bauhaus school and the Ukrainian avant-garde. It is enough to compare several samples of avant-garde art - sketches, posters, graphics and paintings - to see their similarity. However, immersion in the world of elements of this art, identifying patterns of development of form can give us an answer to more substantive questions. Their solution really lies in the field of art criticism and depends on the context of the interaction of a particular artist with other groups. And in any case, at the end of the creation of a particular work of art, we receive a new message, which by establishing the relationship between the various structures brings closer to the artist's idea, to its significance in the context of his era.

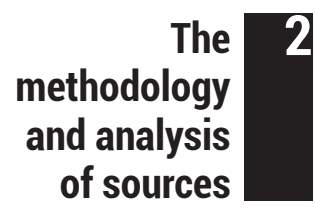

The methodological basis of the study are structural analysis, deconstruction, formal-stylistic and comparative analysis. Structural analysis in this case is to identify and distinguish certain structures in works of art, comparing them in use by different artists and identifying the relationship between them. The method of deconstruction is used to identify the hidden content embedded in the work of the author, to study the nature of the dialogue between different 
avant-garde texts in order to identify the deep content embedded by the author.

The research is based on the analysis of works of art and their correlation with the theoretical works of Bauhaus representatives. And also - on the facts and rethinking of art studies about the Ukrainian avant-garde T. Pavlova (2012; 2013; 2018), D. Horbachov (2011), V. Faber (2019a; 2019b).

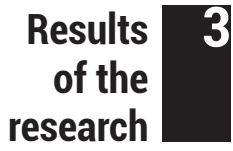

Modernism artists drew attention to the artistic elements, making them the initial coordinates of the New Art. Kazimir Malevich spoke about the main role of color and texture - those entities that have always been killed by the plot. Bauhaus teachers Paul Klee and Vasyl Kandinsky, starting from a point and a line on the picture plane, endowed them with a mission of creating «new substance» and new meanings through the artist's self-reflection and its inclusion in the context of the world and modernity. The same elements of a point, a line and a picture plane were investigated theoretically and practically by the Kyiv painter Olexandr Bohomazov: the results of his research, presented in 1914, were significantly ahead of Kandinsky and Klee (Bohomazov, 1996). It is also significant that Bohomazov and Viktor Palmov worked on the development of color theory at the Kyiv Art Institute, and, despite similar studies by Klee, Kandinsky, and Itten at the Bauhaus, came to phenomenally similar results. In addition, artists-innovators often argued among themselves about the question of form, which is evidenced not only in numerous theoretical articles and treatises, but also in their own works of art. Therefore, often in their work we recognize reminiscences and allusions to each other, or the development of a certain creative method in their own direction. The obvious intertextual dialogue of most artists of that time prompts us to consider the elements of form as separate structures, which, according to our hypothesis, form the phenomenon of new visual thinking. Tracking these structures in the texts and between the texts will confirm or refute the hypothesis.

For the founders of the Bauhaus, the new visuality could not grow simply from the abandonment of naturalistic thinking and academic norms. It was to be awakened in the layers of the inner world, on the one hand, through immersion in the origins of art, on the other hand, in self-knowledge. The result of such work was the theoretical work of V. Kandinsky and P. Klee, which were organized by artists during their teaching in the Bauhaus courses. The knowledge acquired in this way allowed to systematize the elements of form, to help them become recognizable structures with formative properties.

The transition from the expressionist to the constructivist period is significant in the Bauhaus. It is associated with the arrival of Laszlo Moholy-Nagy, an avant-garde of Hungarian descent, who 
replaced Itten as master of the «basics» course (Gomperts, 2017, p. 251). Experiments with new forms become especially interesting for him. Suprematism and abstractionism, which can also be recognized in Moholy-Nagy, suddenly fit into the system of spatial coordinates and allow to reveal the figures in their unfolding in space. And this, in fact, can be called a constructivist interpretation of Suprematism and abstractionism. Undoubtedly, the passion for photography played a significant role in this approach of Moholy-Nagy, and the use of abstraction and photomontage created new opportunities for graphic design.

In parallel with the Bauhaus in Germany and with other avant-garde trends in Western Europe in Ukraine, the avant-garde movement developed rapidly. One of its brightest representatives was the Kharkiv artist and designer Vasyl Yermylov. An interesting interpretation of Bauhaus's innovative ideas can also be observed in his creative methods, which is a well-known fact today (Pavlova, 2013). Yermylov's dialogue with the art of Oscar Schlemmer is especially noticeable (it is enough to compare several counter-reliefs of each of them to recognize the kinship of these masters). But the task of this article is to highlight the results of a somewhat unexpected discovery of the presence of other representatives of the Bauhaus in Yermylov's work and worldview - Moholy-Nagy, Kandinsky and Klee.

It is known that when Ermylov's works appeared at European exhibitions, they were a brilliant success: a gold medal for works at an exhibition in Leipzig (1922); success of works in Paris (1925), high marks and awards at the International Press Exhibition in Cologne, Germany (1928). Regarding the latter, Yermylov made exhibits for the Ukrainian department of the USSR pavilion decorated by V. Meller (Pavlova, 1913, pp. 60-61). But was the artist himself abroad? According to researchers, Yermylov was not allowed to go to Cologne (Tsymbal, 2018). It is likely that victories in 1922 were also won without the presence of the author. Instead, it is known about the artist's keen interest in everything that took place in the Western European avant-garde, and especially in the Bauhaus. This is evidenced by Bauaguz's books in Yermylov's archive: the archive's expert Dmitro Horbachov explains their origins by trips to Germany by Yakiv Rudensky, who dealt with printing issues and brought such valuable publications for artists (Pavlova, 2013, p. 64). We must say that the interest in the European avant-garde was generally inherent in the artistic environment, as evidenced by publications in the most popular pan-futurist magazine «New Generation». In the absence of personal contact with Bauhaus, reviews of them were often based on the French publication «Cahiers d'Art» (Faber, 2019a, p. 10). This was not enough for Yermylovs' desires, but that is why the grasp of ideas in their essence and their inclusion in the dialogical context of 
his own works really testified to the spiritual kinship of the master with the innovation of Western European artists. What Schlemmer and Bayer designed in Weimar and Dessau, Yermylov did in Kharkiv. He combined in his work everything that was at hand: plywood, metal, wood and more. His design includes all types of graphic design - from books, avant-garde magazines to the development of trademarks, packaging design, fabric design and the creation of new fonts. Yermylov is also associated with the use of a prototype of a modular grid, which has become a business card of the Swiss style.

Let's turn to Yermylov's collage diptych «On the beach» (figs. 1.1, 1.2). It was completed as early as 1935 , but contains obvious traces of internal dialogue with the fundamental principles of avant-garde, as they were formed in the Bauhaus.
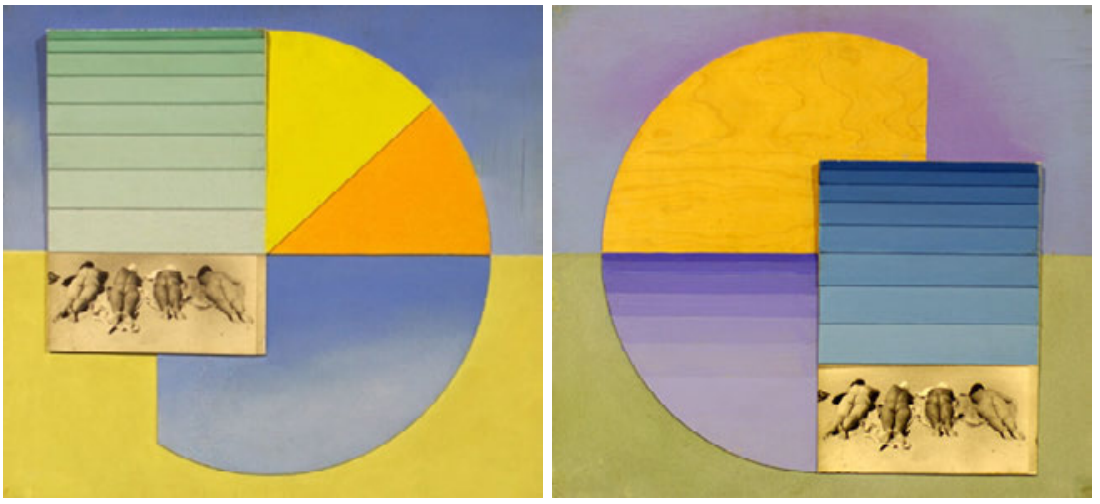

Fig. 1.1. Vasyl Yermylov. On the beach. Morning. The left part of the diptych (relief). 1935. Wood, oil, photo collage. $55 \times 60.5 \mathrm{~cm}$. Collection of K. Grigorishin (Moscow).

Рис. 1.1. Василь Єрмилов. На пляжі. Ранок. Ліва частина диптиха (рельєф). 1935. Дерево, олія, фотоколаж. 55х60,5 см. Збірка К. Григоришина (Москва).

Fig. 1.2. Vasyl Yermylov. On the beach. Evening. The right part of the diptych (relief). 1935. Wood, oil, photo collage. $55 \times 60.5 \mathrm{~cm}$. Collection of K. Grigorishin (Moscow).

Рис. 1.2. Василь Єрмилов. На пляжі. Вечір. Права частина диптиха (рельєф). 1935. Дерево, олія, фотоколаж. 55×60,5 cм. Збірка К. Григоришина (Москва).

Yermylov marked the diptych as a relief. Each of its parts consists of several planes superimposed on each other. One of the fragments is composed of a photo with four naked female figures in beach poses looking from the back. And although Yermylov did not refer to photography often (Pavlova, 2012, p. 66), but in the diptych its application is truly virtuoso. The researcher of the Kharkiv avant-garde views the work in a Dadaist context noting that Yermylov's diptych «completely fit into the context of the ideas of sports and the cult of a healthy body», typical of the 1930s (Pavlova, 2012, p. 65). Indeed, it remained 
only with hidden humor to skillfully conceal the absurdity of cultivated «values» at a time when the real - spiritual, aesthetic, human - was given a place only among the «hostile bourgeois».

The photograph itself belongs to the Odessa photo shoot and, according to T. Pavlova, «illustrates the laws of film editing here: one frame in different contexts reveals different semantic and emotional qualities» (Pavlova, 2012, p. 66). In addition, in our opinion, photography in this case is an innovative way of introducing naked nature into the work, which may be part of the artists' discussion of nature in art, a paradigm shift in its perception, 1923), and, of course, a new visual (Moholy-Nagy, 1925; 1947). Analyzing Ermylov's nude as a structure, we can state its unusual interpretation: first, the view from the back depersonalizes (this is not a portrait); secondly, deprives the face (devalues the need to identify individual traits); and, thirdly, multiplies the nu by four, revealing their common features, and thus brings them closer to the usual elements of form placed on the canvas in a certain rhythm. In addition, interpreted through an unusual angle, the four nudes are reduced in such a way as to create an optical illusion of the third dimension, which consists, in particular, in the relief separation of the perpendicular plane from the main, interpreted plane. There is a visual impression that the relief in the work occurs precisely because of the ratio of the photocell and the main plane.

In this case, it is also important that Yermylov collages a blackand-white photograph with color-geometrized flat elements. In each of the parts there is an amazing sense of balance and equality of the elements: it is interesting that in the composition there is no subordination of one element to another. Photography also has its «weight». This equality, in fact, looks so programmatic that it forces us to turn our attention to the recognition of the message that captures the results of solving the problem of the art plan.

It is not for nothing that Yermylov creates two collages, the difference of which is revealed in three ways: due to color saturation, due to change of textures or rhythmization of color planes and due to change of photo position in the collage (the latter can also be associated with moving the sundial). Color - its heat, intensity, voltage - serves to identify the degree of increase and decrease of this temperature.

The photograph with lying figures in a sharp perspective reduction resembles the avant-garde work «City Lights» (fig. 2.1), what prompted us to the thought that Yermylov borrowed this method with the use of photo from Moholy-Nagy. It is not difficult to note that the segmented space of Yermylov's collage could refer to the geometrically complicated space of Moholy-Nagy, where the segments create the effect of searchlight rays, in the projection of which there are two female figures in swimsuits. Interestingly, the «project- 
Деміург: ідеї, технології, перспективи дизайну 2020 Том 3 № 1

Demiurge: ideas, technologies, perspectives of design 2020 Vol. 3 No 1

ed» image does not reach the plane and visualizes the figures in a specific perspective reduction. Experiments with perspective were characteristic of Moholy-Nagy - in order to distract the viewer from her usual interpretation. On the other hand, the formed planes behave as typical «picturesque entities» actualized by abstractionists. Intersecting with each other, they create a self-sufficient harmony of elements. It seems that in the work Moholy-Nagy uses reminiscence of his earlier abstract work (fig. 2.2). The introduction of a photographic image placed in the «field of view» of another figure, turns the work into a constructivist and shifts the focus to the spatial aspect.
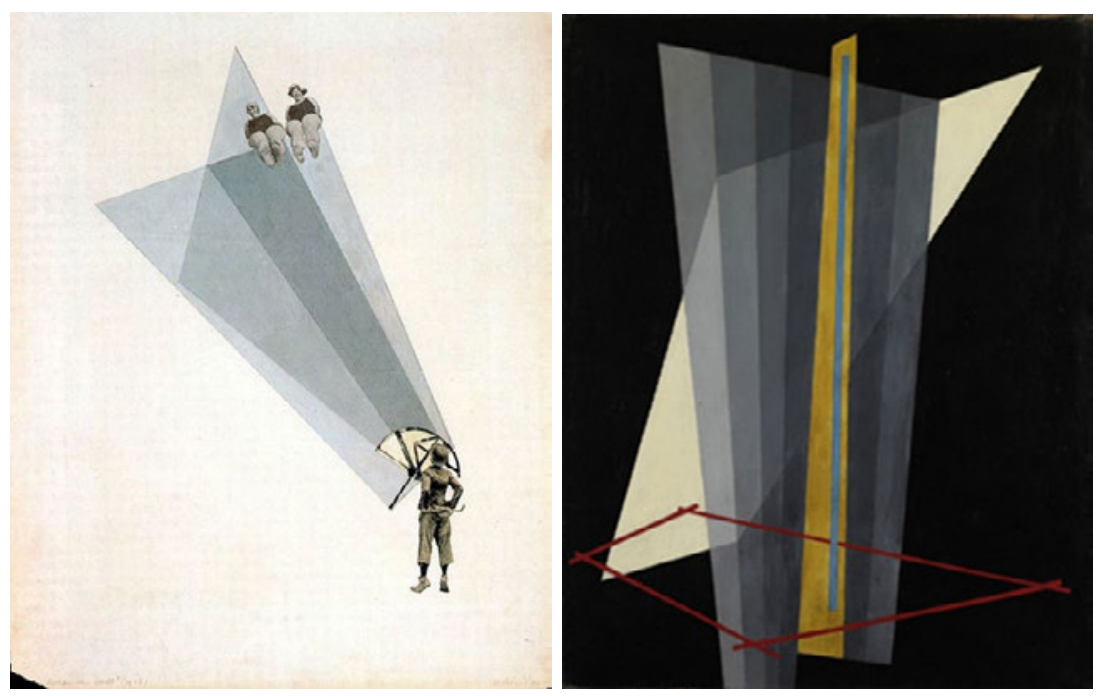

Fig. 2. 1. Laszlo Moholy-Nagy. City Lights. Photomontage. 1926. Collage with ink and watercolor on paper. $61 \times 48 \mathrm{~cm}$. Bauhaus-Archiv, Berlin.

Рис. 2.1. Ласло Могой-Надь. Міське світло. Фотомонтаж. 1926. Колаж чорнилом та аквареллю на папері. 61 ×48 см. Архів Баугаузу, Берлін.

Fig. 2.2. Laszlo Moholy-Nagy. Construction. 1922. Oil on panel. Harvard Art Museums / Busch-Reisinger Museum collection. .

Рис. 2.2. Ласло Могой-Надь. Конструкція. 1922. Олія, дошка. Гарвардські художні музеї/ Музей Буша-Рейзінгера.

Naked nature in Yermylov's photography is presented in a more frank interpretation, and it is quite possible that it argues with the half-naked nature of Moholy-Nagy: after all, if we are talking about the theme of nature in art, then it must necessarily appear naked. According to our observations, the appearance of nude in an unexpected context has always been used by artists not by chance in order to sharpen attention to the state of painting, or to capture 
a purely artistic problem that seeks a radical change of form (just mention «Artist's Studio» by Gustave Courbet or «Olympia» and «Breakfast on the Grass» by Edward Manet).

Could Yermylov really refer to Moholy-Nagy's work in the diptych? According to T. Pavlova (2013, p. 64), among the books of the Bauhaus Yermylov definitely had the eighth edition with the work of Moholy-Nagy (1925). However, this reproduction was not in the mentioned book. In any case, the photo collage, created in 1926 or 1928 (dating differs in different sources), had every chance to be seen by Yermylov by 1935. Other photo collages by Moholy-Nagy, included in both the book and and in other editions of the Bauhaus (figs. 3).
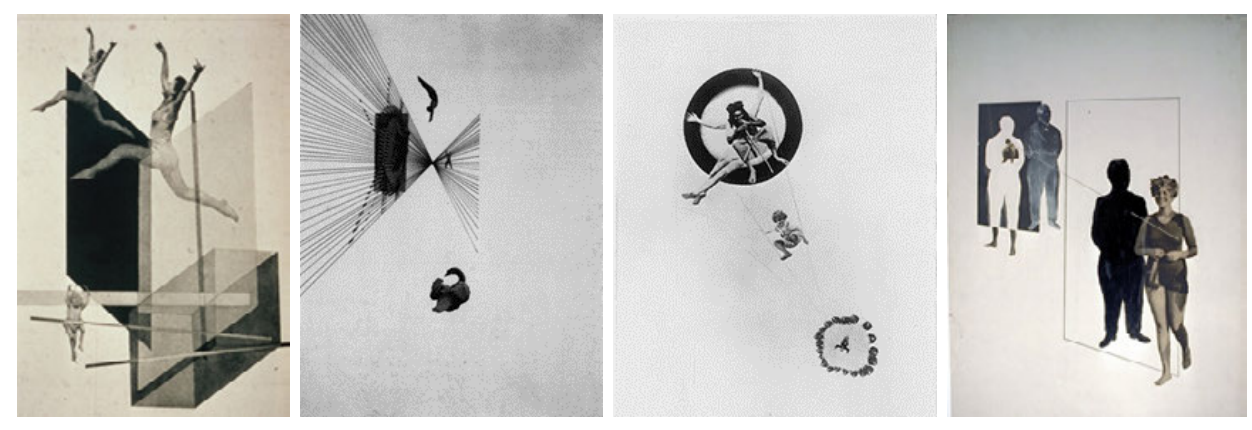

Fig. 3. Laszlo Moholy-Nagy. Photomontage examples: Human Mechanics, 1925; Leda and the Swan, 1925; Between Heaven and Earth, 1925; Jealousy, 1924 - 27.

Рис. З. Ласло Могой-Надь. Зразки фотомонтажу 1925 - 1927 рр.: Human Mechanics, 1925; Леда і лебідь, 1925; Між небесами і землею, 1925; Ревнощі, $1924-27$.

In addition, thematically Yermylov's diptych echoes the «beach» series of photographs of Moholy-Nagy in 1926 and 1930 in Ascona, Switzerland (figs. 4.1-4.3). The most famous of this series is the photo masterpiece "Oscar Schlemer in Ascona» (fig. 4.2). However, more interesting in our case is the photo «Siesta» (fig. 4.1), taken in the same entourage using a sharp reduction, similar to that used in the photocell from the «City Light» (fig. 2.1). The photo from Ascona Beach in 1930 (fig. 4.3) is composed of two different textured planes, which can be considered facing each other with the same geometric shapes. However, optically they differ due to the wide bands of the lower plane and the small pattern of the water surface - the upper. Bare legs here become a vertical motif. So, in this photo, at least three structural elements could have inspired Ermylov to create his own «beach». 

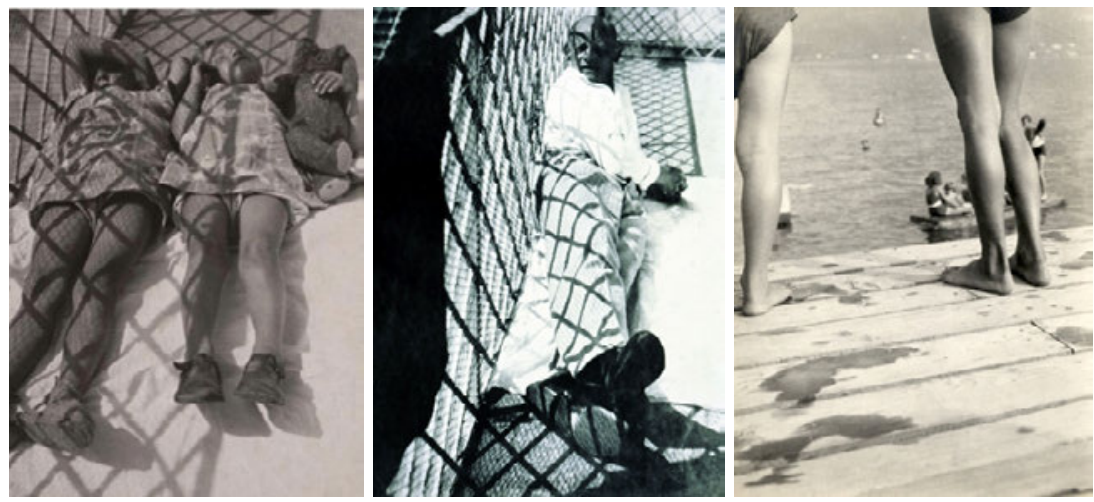

Fig, 4. 1. Laszlo Moholy-Nagy. Siesta (Schlemmer's girls on balcony). 1926. 39,8×29,9. Galerie Berinson, Berlin; Ubu Gallery, New York.

Рис. 4. 1. Ласло Могой-Надь. Сієста (Доньки Шлеммера на балконі). 1926. 39,8x29,9. Galerie Berinson, Берлін; Ubu Gallery, Нью-Йорк.

Fig, 4.2. Laszlo Moholy-Nagy. Oskar Schlemmer in Ascona. 1926. 16,8x12,4. Galerie Berinson, Berlin; Ubu Gallery, New York.

Рис. 4.2. Ласло Могой-Надь. Оскар Шлеммер в Асконі. 1926. 16,8х12,4. Galerie Berinson, Берлін; Ubu Gallery, Нью-Йорк.

Fig, 4.3. Laszlo Moholy-Nagy. Lago Maggiore, Ascona, Switzerland. ca. 1930 Gelatine silver print. 20,8 × 28,4 cm. Collection Spaarnestad Photo: Nationaal Archief.

Рис. 4.3. Ласло Могой-Надь. Lago Maggiore, Аскона, Швейцарія. Близько 1930. Колекція Spaarnestad Photo: Національний архів.

The photo used in Yermylov's photo collage was not the only one from the Odessa photo shoot (Pavlova, 2012, p. 66). And her other photos also testify to Yermylov's high skill with the use of techniques close to those used by Moholy-Nagy.

However, the presence of Moholy-Nagy in Yermylov's work still does not allow us to penetrate into the non-Dadaist context of Yermylov's diptych. Vasyl Kandinsky's theoretical work Point and Line to Plane opens up new facets of his idea. Considering the elements of form and features of their interaction on the pictorial plane, «For the concept» movement, "which is used almost everywhere», Kandinsky proposes to use the term «tension». "Tension is the force living within the element and represents only one part of the creative «movement». The second part is the «direction», which is also determined by the «movement». And by the elements of painting Kandinsky understood the material results of movement in the form: 1 - of the tension, and 2 - of the direction (Kandinsky, 1947, pp. 57-58).

In our opinion, both parts of the diptych «On the Beach» act as a similar system of tensions. You could even say that each of the parts is a kind of mathematical coordinate system, in which the balancing and solving of tensions is carried out depending on the fixed 
direction. Differences in the two parts of the diptych - in the location of colors, their combinations and the relief plane with the photo collage, superimposed on another plane.

In the analysis of the elements of form, Kandinsky also introduces a seemingly unusual category of «temperature». It is fixed primarily on a certain type of lines. Thus, the horizontal is a «cold bearing base», and the plane formed by it is endowed with «cold» and «it can be designed as the most concise form of the potential for endless cold movement». The vertical, «which stands at right angles to it, and in which flatness is supplanted by height, and coldness by warmth», is defined as «the most concise form of the potential for endless warm movement» (Kandinsky, 1947, pp. 58-59). The third type of straight line is the diagonal «which, in schematic form, diverges from both of the above at the same angle and, therefore, has the same inclination to both of them; a circumstance which determines its inner sound - equal union of coldness and warmth. Therefore, the diagonal line is the most concise form of the potential for endless cold-warm movement». All other lines are certain deviations from the diagonals and their sound determines the differences in a greater or lesser tendency to cold ness or to warmth determine their inner sounds» (Kandinsky, 1947, p. 59).

All three types of lines are formative in Yermylov and build an interesting constellation of «thermal tension», which we feel in ordinary contemplation: the collage evokes a range of associations, among which the feeling of temperature contrasts plays almost the most important role. Thus, due to the reception of the gradient image there is a feeling of gradual increase and decrease of temperature; there is a suggestive association with a summer beach with the shining sun and the coolness of the sea.

Of course, to see this effect, the viewer does not have to dive into Kandinsky's theoretical search, but such analysis of structures reveals interesting process of Yermylov's visual thinking, the desire to participate in the development of universal visual language in art. In addition, such an approach, even under the close supervision of the system for the artist, allowed a covert escape into the realm of avant-garde art, which was already banned at the time. Since such language was incomprehensible to the system, it became a kind of «slang» for artists to express their true thoughts.

In Yermylov's diptych, all the elements are brought into balance in such a way that they actually become «the inner significance of the tension of the Basic Plane» (Kandinsky, 1947, p. 136).

And if we analyze in the work the categories that Kandinsky defines as a kind of markers in determining the interaction of «tensions» (top, bellow, left and right), we get important results.

In the left part of the diptych «Morning» (fig. 1.1) a striped rectangle with a photo collage is located in the upper left part of the 
main plane. According to Kandinsky, «the «above» gives the impression of a great looseness, a feeling of light ness, of emancipation and, finally, of freedom». He also notes that «this» looseness «is a negation of density. The nearer to the upper border of the Basic Plane the smallest individual areas seem to be, the more disintegrated they appear) (Kandinsky, 1947, p. 115). Such a loss of density can be felt in the mentioned fragment of «Morning». Despite the fact that the color with upward movement here becomes more intense, and the distance between the stripes decreases - the amazing effect of «thinning», «breathing» remains. However, the photograph itself as a «heavy» part of the fragment remains outside the upper case and thus somewhat balances the «dissolution» of the upper plane.

Kandinsky experimentally determined the features of the interaction of elements on the plane in different contexts. Considering the degree of tension on a square plane divided into four, the artist concludes that the most free is the combination in the upper left segment (Kandinsky, 2011, p. 187). This thesis, again, corresponds to the placement of a plane with a photo collage in «Morning», where Yermylov chose the best constellation of «freedom» on the main plane, in which «east» becomes intense, and «restraint is reduced to a minimum») (Kandinsky, 1947, p. 117).

It is also possible to apply the category of «below» of Kandinsky to the description of a similar fragment in the right part of Yermylov's collage («Evening») (fig. 1.2). «The effect of «below» is completely contrary: condensation, heaviness, constraint. The closer one approaches the lower border of the Basic Plane, the denser the atmosphere becomes; the smallest individual areas lie nearer and nearer together and thereby sustain the larger and heavier forms with ever in creasing ease», - says Kandinsky (Kandinsky, 1947, p. 117). But «Climbing» becomes more difficult - the forms seem to tear themselves loose by main force». Kandinsky even describes the «sound experience» of lower case forms: «the grating noise of friction is audible» (Kandinsky, 1947, p. 117).

In «Evening» the placement of the plane with the photo collage also fully corresponds to Kandinsky's statement about the maximum resistance, which is given to the placement in the lower right segment (fig. 1.2). Here it signifies «The one to the «right»-centered inwardly - is a movement toward home. This movement is combined with a certain fatigue, and its goal is rest» (Kandinsky, 1947, p. 121). The stroke slows down, the voltage weakens.

In his work, Kandinsky explained that «ldeas like movement, climbing, falling, etc. are derived from the material world. On the pictorial Basic Plane they are to be understood as the tensions living within the elements, which are modified by the tensions of the BP (Basic Plane)» (Kandinsky, 1947, p. 117). And Yermylov, apparently, also arranges a «battlefield» on his pictorial plane, overcoming «ten- 
sions», overcoming the material within the plane itself, while leaving a certain message to the viewer in this new visual language. In our opinion, this is the key point: Yermylov teaches his viewer to «weigh» the picturesque elements on the basis of expansion - compression, heat - cold, lightness - heaviness, freedom - tightness, and so on.

As for the color, Yermylov's diptych is done in the tonal range of the main colors - yellow and blue. According to Kandinsky's theory, these two colors "carry within them different tensions - tensions of advancing and retreating». Colors give shape to its «sound» (Kandinsky, 1947, p. 62). Accordingly, in Yermylov's «morning beach» one quarter of the circle (upper right) is divided into segments of yellow and orange, which can really be felt as the highest degree of heat. They form acute angles, which, according to Kandinsky, are endowed with the greatest tension, and they are the warmest (Kandinsky, 1947, p. 62).

Instead, in the «evening» sample there are no sharp corners. There is a certain constellation of right angles, the skillful weighing of which resembles the reception of Mondrian. Kandinsky (1947) alls the right angle the most objective and the coldest (p. 62). Compared to the «morning», this work indicates the attenuation of heat, right angles still suggest coolness.

At first glance, it is not entirely clear how blue corresponds to this scheme in Yermylov's work (after all, red is fixed at right angles in Kandinsky's theory). However, a somewhat more complex metamorphosis occurs here: "The obtuse angle increasingly loses its aggression, its piercing quality, its warmth, and is, thereby, distantly related to a line without angles which, as will be shown below, constitutes the third primary, typical form of the plane - the circle. The passiveness in the obtuse angle, the almost missing forward tension, gives this angle a light blue tone» (Kandinsky, 1947, p. 73).

Interestingly, in «Evening Beach» Yermylov's plane above the photo, painted in warm blue, is in dissonant proximity to the lower left segment of the circle, which is painted in cold blue (while in «Morning» this segment is much warmer). Each of the planes of «Evening» noticeably «fades» relative to the same in «Morning». And most importantly, Yermylov conveyed this relative «fading» not only with color, but also with complex balances of top and bellow, left and right, sharp and right angles, the ratio of lines and planes, giving the elements a certain direction.

Visual association with a fragment reminiscent of a persistent quote hidden «recognizable»: namely, with the embossed part of the photo collage - a square with blue stripes with a gradual gradation of color, leads us to Paul Klee.

On the basis of such «striped forms» Paul Klee created several watercolors (fig. 5.1 - 5.3), and they are found in different variations in the theoretical records of the artist (fig. 6.1 - 6.3). In one place 
Деміург: ідеї, технології, перспективи дизайну 2020 Том 3 № 1 Demiurge: ideas, technologies, perspectives of design 2020 Vol. 3 No 1

after such forms there is a blank page with the inscription: «Streifenflächen nach der Progression de ganzen Zahlen geteit (123456)», which translated from German means: «Striped surfaces after the progression of integers (123456)» (Center of Paul Klee http://www. kleegestaltungslehre.zpk.org/ee/ZPK/Archiv/2011/01/25/00001/).
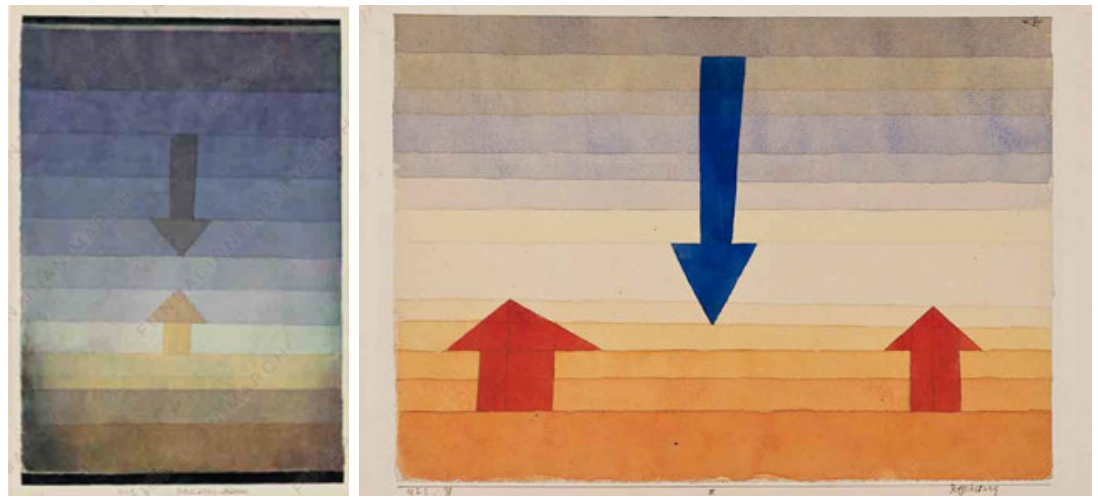

Fig. 5.1. Paul Klee. Separation in the evening. 1922. Watercolor and pencil on paper on cardboard. $33.5 \times 23.2 \mathrm{~cm}$. Center of Paul Klee, Bern.

Рис. 5.1. Пауль Клеє. Розлучення увечері. 1922. Акварель, олівець, папір, картон. 33.5 × 23.2 см. Центр Пауля Клеє, Берн.

Fig. 5.2. Paul Klee. Greetings of life (Begrüssung). 1922. Watercolor, pen and ink on paper, $22.5 \times 31 \mathrm{~cm}$. Wadsworth Atheneum Museum of Art, Hartfort, USA.

Рис. 5.2. Пауль Клеє. Привітання життя. 1922. Акварель, перо, чорнило, папір. 22.5 × 31 см. Художній музей Уодсворд Атенум, Гартфорд, США.
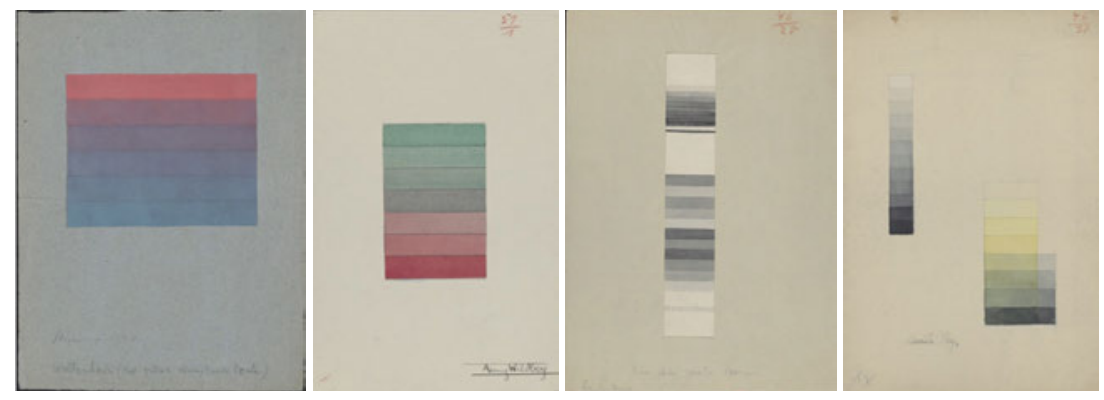

Fig. 6. "Striped surfaces» by Paul Klee in various recordings. Pencil and paints on paper. $33 \times 21 \mathrm{~cm}$. Center of Paul Klee. Bern.

Рис. 6. "Смугасті поверхні» Пауля Клеє у різних записах. Олівець та фарби на папері. $33 \times 21$ см. Центр Пауля Клеє. Берн.

It is quite possible that $\mathrm{V}$. Yermylov could have been inspired by the content of P. Klee's work «Ways of Studying Nature» from the catalog of the first Weimar exhibition of the Bauhaus (Klee, 1923). 
The obvious syncretism of the diptych presupposes the solution of such artistic tasks: "By meeting nature alone, the artist cannot go beyond unity with it. The artist is a man, he himself is nature and a part of natural space» (Klee, 1923, p. 24). Klee explained his vision of the artist's modern interaction with nature, and thus the origins of the new visual, with a schematic drawing (fig. 7.1), in which he pushed artists to self-reflection - to understand the place and task of the artist in the universe. This is expressed by the relationship between the eye of the artist, placed in the diagram on the left, and the nature that focuses in this eye - on the right; streams of impulses from the Earth (below) and the world, space (above) pass through them. It is between these streams that a new visuality is formed in Klee. And it is in this perspective that the master's course at the Bauhaus was aimed at mastering a new form of visual thinking.

In addition, Klee explained the influence of the corresponding flows on the nature of the forms that appear in the work in the above-mentioned conceptual scheme: "The lower path passes the sphere of the static and generates static forms, and the upper path - through the sphere of the dynamic. On the lower path, which gravitationally goes to the center of the earth, the problems of static equilibrium are being solved (...). At the top there is a desire to overcome gravity and move in free motion» (Klee, 1923, pp. 24-25).
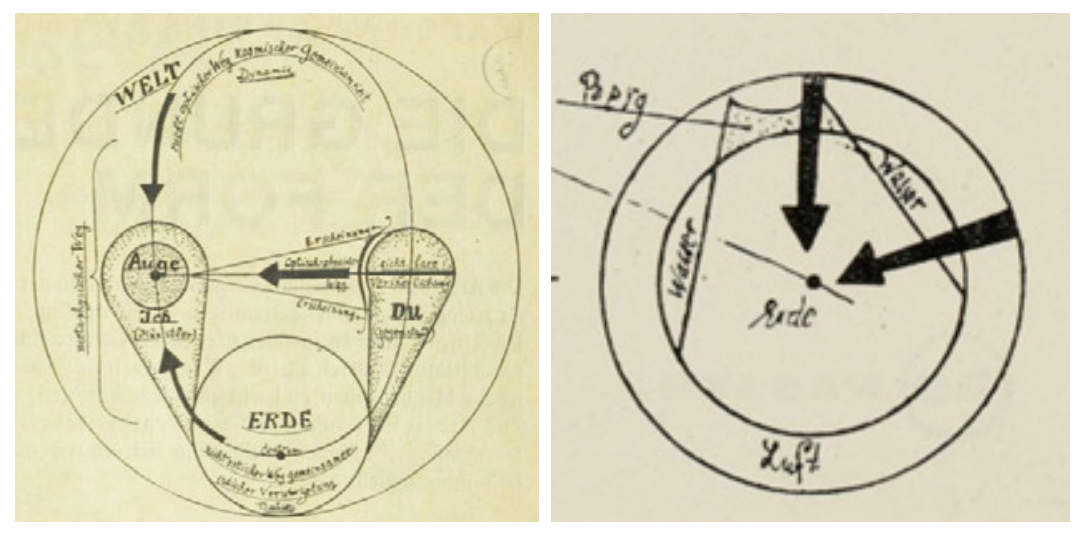

Fig. 7.1. Conceptual scheme for the article «Ways to study nature».

Рис. 7.1. Концептуальна схема до статті «Шляхи вивчення натури».

Fig. 7.2. Earth, water, air: in search of equilibrium.

Рис. 7.2. Пауль Клеє. Земля, вода повітря: у пошуку встановлення рівноваги.

Interestingly, in his another work (Klee, 1925) the artist describes the origin «the purest mobile form, the cosmic one», mostly «through the liquidation of gravity (through elimination of material ties)». He comes to the conclusion that «This moment is imagined 
as occurring while the pendulum is in full swing. It, will circumscribe a circle which is the purest of mobile form» (Klee, 1953, p. 53). In connection with Yermylov, this circle transfers us into a two-dimensional plane, in which the relief element, assembled from a picturesque square element and a photograph, plays the role of a «wandering point» of the pendulum.

Ermylov's diptych resonates with another scheme by Paul Klee, which is aimed at overcoming the disturbed balance «between land, water and air» (fig. 7.2).

Of course, no scheme is cited in Yermylov's work: in our opinion, it is present in the worldview as a marker of the artist's goal and mission. Didn't it become the basis for accusations of cosmopolitanism (Horbachov, 2011) and the expulsion of Yermylov from the Union of Artists, the controlling authority of the Stalinist regime, which decided who of the artists could eat that days and who had to be hungry?

At the same time, the work hides an artistic «slap» to the totalitarian regime and proclaimed social realism with its substitution of the essence of art, in the conditions of which it reveals the true state of affairs through Dadaist context, lack of perspective, cyclicality and isolation within «allowed». The vicious circle is noticeable despite all the brightness of the diptych and the possibility of finding various meanings in it. It contains a similar premonition of the inevitable, as in the writings of Paul Klee: «The contrast between man`s ideological capacity to move at random through material and metaphysical spaces and his physical limitations, is the origin of all human tragedy. It is this contrast between power and prostration that implies the duality of human existence. Half winged - half imprisoned, this is man! Thought is the mediary between earth and world. The broader the magnitude of this reach, the more painful man`s tragic limitation. Motion becomes necessary, but already impossible» (Klee, 1925, p. 44).

Finally, it should be noted that the master's ability to analyze the form reveals the presence of visual language, which can be studied and read, to distinguish its units. This is especially important given that the legacy of the avant-garde has been largely destroyed and their practice has long been banned.

Thus, Yermylov's diptych can be called a brilliantly played part of the «bead game» (so called at the time the popular work of the German writer-innovator Hermann Hesse about a mysterious artistic game with a spiritual connotation). Such a game seems to have become the defining avant-garde method, which captures the real prerequisites for innovation. After all, artists need for the revolution in art form, the desire to get rid of remnants and gain more freedom for creativity tragically coincided with the political trend of Bolshevism in Russia and occupied Ukraine and National Socialism in Germany. 


\section{Scientific 4 \\ The scientific novelty of the research is to identify the origins novelty and and relationships of Vasyl Yermylov's collage "On the Beach» with the works and theoretical developments of Bauhaus representa- tives, which testifies not only to the programmatic and ideological unity, but also to the identity of visual thinking. The results of the study revealed tendencies for Yermylov to create avant-garde com- positions based on a subtle creative dialogue with the theoretical approaches of the Bauhaus representatives. Methods of structural analysis and deconstruction have revealed elements of form that actually become structures, deliberately introduced by the master into the work in order to rethink it, create another combination and, thus, the assertion of new content. This is the first time such an analysis of Yermylov's works has been conducted.}

\section{Conclusions $\mathbf{5}$}

Yermylov's diptych, disguised as Dadaism, testified to the universality of the new visual language, which had developed in spite of attempts to adapt it to the service of the regime with subsequent ban and destruction. Today it is important to testify that Ukrainian artists developed in harmony with their Western counterparts. However, in our opinion, to explain the identity of their visual thinking and creative approaches solely by influences would be a mistake (because they have repeatedly testified to their own superiority). Rather, the exchange of ideas, complementarity, thanks to which the intercultural relations have become a universal visual language still relevant today, are worth emphasizing. In the end, if we can study the theoretical approaches of the Bauhaus masters - Kandinsky, Klee, Moholy-Nagy and others - through Yermylov's work, then the master achieved his goal: he stated the effectiveness of the new visuality and did it in an ingeniously simple universal way.

\section{References}

Bohomazov, O. (1996). Zhyvopys ta elementy [Painting and elements]. Zadumlyvyi straus [in Ukrainian].

Faber, V. (2019a). Bauhauz ta Nova Generatsiia - kontakty, impulsy, analohii [Bauhaus and New Generation - contacts, impulses, analogies]. In Materyk ukrainskoho avanhardu na mapi svitu [The Continent of the Ukrainian Avant-Garde on the World Map], Proceedings of the International Scientific and Practical Conference (pp. 4-16). MTMCU [in Ukrainian].

Faber, V. (2019b). Die ukrainische Avantgarde zwischen Ost und West. Intertextualität, Intermedialität und Polemik im ukrainischen Futurismus und Konstruktivismus der späten 1920er-Jahre [The Ukrainian avant-garde between east and west. Intertextuality, intermediality and polemics in Ukrainian futurism and constructivism of the late 1920s]. Transcript [in German].

Gomperts, W. (2017). Shcho tse vzahali take? 150 rokiv suchasnoho mystetstva v odnii piliuli [What Are You Looking At? 150 Years of Modern Art in the Blink of an Eye] (L. Belei, A. Koriahina, \& I. Zaitseva, Trans.). ArtHuss [in Ukrainian].

Horbachov, D. (2011). Moi zustrichi z heniiem dyzainu [My meetings with the genius of design]. Art Ukraine, 3, 118-123 [in Ukrainian].

Kandinsky, V. (1947). Point and line to plane. Dover Publications [in English]. 
Kandinsky, V. (2011). Tochka i liniia na ploskosti [A point and a line on the plane] (E. Kozina, Trans.). Azbuka [in Russian].

Klee, P. (1923). Wege des Naturstudiums [Ways of studying nature]. In Staatliches Bauhaus in Weimar 1919-1923. Katalogbuch [Staatliches Bauhaus in Weimar 1919-1923. Catalog book] (pp. 2425). Albert Langen Verlag. https://digital.slub-dresden.de/werkansicht/dlf/193521/28/0/ [in German].

Klee, P. (1925). Pädagogisches Skizzenbuch [Educational sketchbook] (Bauhausbücher 2). Albert Langen Verlag. https://www.bauhaus-bookshelf.org/bauhaus_book_2_paul_klee_ pedagogical_sketchbook_pdf_download.html [in German].

Klee, P. (1953). Pedagogical Sketchbook. Frederick A. Praeger publishers [in English].

Moholy-Nagy, L. (1925). Malerei Fotographie Film [Painting Photography Film] (Bauhausbücher 8). https://www.bauhaus-bookshelf.org/bauhaus_book-8-moholy-nagy-painting-photographyfilm-pdf-1925.html [in German].

Moholy-Nagy, L. (1947). The New Vision and Abstract of an Artist. Wittenborn, Schultz. https:// www.bauhaus-bookshelf.org/bauhaus-book-14-moholy-nagy-von-material-zu-architekturpdf-1930.html [in English].

Pavlova, T. (2012). Vasyl Yermylov zhde vesnu [Vasily Yermylov is waiting for spring]. Rodovid [in Ukrainian].

Pavlova, T. (2013). Vasyl Yermilov: vid kharkivskoho "Bavhauzu" do Kyivskoho khudozhnoho instytutu [Vasyl Yermylov: from Kharkiv's Bauhaus to Kyiv Art Institute]. Aktualni problemy mystetskoi praktyky i mystetstvoznavchoi nauky. Mystetski obrii'2013, 5(16), 59-65 [in Ukrainian].

Pavlova, T. V. (2018). Avanhard v obrazotvorchomu mystetstvi Kharkova XX stolittia [Avant-garde in the fine arts of Kharkiv in the 20th century]. (Doctoral Dissertation). Lviv National Academy of Arts, Lviv [in Ukrainian].

Tsymbal, Ya. (2018, June 10). Ukrainskyi avanhard forever [Ukrainian avant-garde forever]. Tyzhden. ua. https://tyzhden.ua/Columns/50/215041 [in Ukrainian].

Vasilii Ermilov: katalog vystavki [Vasyl Yermylov: exhibition catalog]. (2011). Proun [in Russian].

\section{The Source of illustration}

Fig. 1.1. URL: https://www.wikiart.org/en/vasyl-yermylov/on-the-beach-morning-evening-1936

Fig. 1.2. URL: https://www.wikiart.org/en/vasyl-yermylov/on-the-beach-morning-evening-1936

Fig. 2.1. URL: https://www.wikiart.org/en/laszlo-moholy-nagy/city-lights-1926

Fig 2.2. URL: https://hvrd.art/o/222926

Fig. 3. URL: https://www.wikiart.org/en/laszlo-moholy-nagy/human-mechanics

URL: https://www.wikiart.org/en/laszlo-moholy-nagy/leda-and-the-swan-1925

URL: https://commons.wikimedia.org/wiki/File:Behind_the_Back_of_the_Gods_MET_DP111634.jpg

URL: https://commons.wikimedia.org/wiki/File:Behind_the_Back_of_the_Gods_MET_DP111634.jpg

Fig, 4.1. URL: https://www.wikiart.org/en/laszlo-moholy-nagy/siesta-1926

Fig, 4.2. URL: https://www.wikiart.org/en/laszlo-moholy-nagy/oskar-schlemmer-in-ascona-1926

Fig, 4.3. URL: https://www.wikiart.org/en/laszlo-moholy-nagy/lago-maggiore-ascona-switzerland

Fig. 5.1. URL: http://www.emuseum.zpk.org/eMuseumPlus

Fig. 5.2. URL: https://commons.wikimedia.org/wiki/File:Begr\%C3\%BCssung_by_Paul_Klee__1922.jpg

Fig. 6. URL: http://www.kleegestaltungslehre.zpk.org/ee/ZPK/Archiv/2011/01/25/

Fig. 7.1. (Klee, 1923, p. 25).

Fig. 7.2. (Klee, 1925, p. 37). 